\title{
A Review of Impact of Personality Big Five, Self-Efficacy and Autonomy on Job Satisfaction Among Employees
}

\author{
Abdah Ishak*, Mastura Mahfar, Halimah Mohd Yusof \\ Faculty of Management, Universiti Teknologi Malaysia, 81310 UTM Johor Bahru, Johor, Malaysia
}

*Corresponding author: abdah@.utm.my

\begin{abstract}
Job satisfaction is predicted to influence employee's decision, behavior and productivity in the organisation. Previous studies had shown a significant relationship between job satisfaction and employees' satisfaction. The purpose of this study is to investigate the impact of Personality Big Five dimensions, self-efficacy and autonomy on job satisfaction. The review will explain the influence of self-efficacy between Personality Big Five and job satisfaction and the link of autonomy between self-efficacy and job satisfaction mostly on employees' satisfaction.
\end{abstract}

Keywords: Personality big five, self-efficacy, autonomy, job satisfaction

\begin{abstract}
Abstrak
Kepuasan kerja diramal akan mempengaruhi keputusan, tingkah laku dan produktiviti pekerja dalam organisasi. Kajian-kajian lepas telah menunjukkan hubungan yang signifikan antara kepuasan kerja dan kepuasan pekerja. Tujuan kajian ini dijalankan adalah untuk menyelidik kesan dimensi Personaliti Big Five, efikasi kendiri dan autonomi terhadap kepuasan kerja. Kajian ini akan menjelaskan pengaruh efikasi kendiri antara Personaliti Big Five dan kepuasan kerja dan hubungan autonomi antara efikasi kendiri dan kepuasan kerja terhadap kepuasan pekerja.
\end{abstract}

Katakunci: Personaliti Big Five, efikasi kendiri, autonomi, kepuasan kerja

(C) 2016 Penerbit UTM Press. All rights reserved

\subsection{INTRODUCTION}

An organization needs to change in line with globalization. Technology development and human resources would be involved in the process of adapting into the changing technologies (Liao et al, 2008). Technological knowledge, skills and competency are important assets for both individual and organization (Liao et al, 2008). These assets are able to improve the performance of the organization and will increase job satisfaction if they are deeply recognized (Myung et al, 2012). Job satisfaction is predicted to influence employment decisions in everyday life, influence behavior, affects employee's morale, commitment and productivity (Carlos et al, 2012). In this study, job satisfaction is reviewed because it will assist organisation to develop effective strategies on employee's satisfaction, provides great benefits in acquiring potential staff and ensuring the future of individuals (Homa et al, 2014).

According to Klaus (2012), job satisfaction is defined as the positive emotional state of one's work experience or the pleasure of working, varying according to one's perception and influenced by aspects of the work environment. Job satisfaction is a repeated behavior that requires constant management which will enhance performance and behavior of the organization (Saifuddin et al, 2012). The determinant of job satisfaction is subjective, has a broader meaning and does not depend on the nature of the job or regulations but through one's perception and evaluation which involves many factors such as wages and working conditions (Felissa, 2004). Oladipo et al, (2014) asserted that job satisfaction involves individual's satisfaction intrinsically (ability, initiative, relationships with others) and extrinsically (salary, promotion, welfare), work performance, what employee felt about his job and emotional reactions between feeling and work characteristics (Vivian, 2005).

Previous studies had shown that job satisfaction is also important to retain employees in an organization and bring an impact on the organization in achieving its goals (Heidi, 2012, Judge et al, 2002). Job satisfaction also will spark enthusiasm in doing work and profitable to the organization, whereas employees who are not satisfied will face frustration, demotivated and thus, it will increase the turnover (Jusuf, 2012). Gauri (2013) investigated among staff members of nine different long-term care facilities located in different parts of southern US showed that employees who faced roles conflict and workload experienced decreasing in work performance, thus decrease in personal satisfaction will affect the quality of care given to their patients and the organization's performance. Whereas, employees who achieve job satisfaction will understand customers' needs, have better interaction with customers and fulfill customers' requirements 
(Ramendra et al, 2013, Pettijohn et al, 2002). The consistent findings prompted that further research need to be carried out to investigate on job satisfaction (Fauziah et al, 2009).

Beside that, the researcher will investigate the relationship between personality and job satisfaction because past studies have shown that personality is also an element that influenced job satisfaction (Chang et al, 2010). According to Zainal et al, (2009) personality has become a favorite topic of many researchers and many theories of personality have been established to explain individual's behavior. Personality is defined as individual's attititude which influenced the emotion, motivation, cognitive and readiness of the mind to react in a certain way (Homa et al, 2014). Employee behaves based on their own personality and this provides information on how an employee reacts in different situations (Heidi, 2012). The relationship between personality and job satisfaction is an important element in determining the employee's efficiency, high performance and productivity in the organization, thus relatively alert the organization to be more attentive in enhancing intrinsic motivation and in implementing human resource management policies effectively (Chang et al, 2010).

On top of that, the researcher will investigate the influence of self-efficacy between Personality Big Five and job satisfaction because by adding its effects on job satisfaction, self-efficacy is perceived as a cognitive mechanism that controls one's behaviour, influences feelings, ways of thinking, ability in implementing and managing tasks effectively (Rita, 2000). Self-efficacy has been growing in modern organizations and influences an individual's actions intrinsically and extrinsically in decision-making, work-related problems and goal setting (Sven, 2008). Self-efficacy has an impact on attitude, making judgments wisely enhance individual's work performance in a variety of ways include mastering difficult and challenging tasks (Aikaterini et al, 2014). Self-efficacy is a self-development that contributes to high commitment and achievements, able to reduce depression, stress and failures (Oyewumi et al, 2012). An individual with high self-efficacy is independent, smart in controlling and commanding, efficient in addressing his tasks, comfortable in his jobs, able to overcome pressures in work and able to achieve organizational goals (Ulfiani et al, 2014).

Hence, in the organization, self-efficacy is also an important and effective predictor to evaluate employee job satisfaction, bring implications for the recruitment and retention of employees (Hui-Fang, 2007). The relationship between self-efficacy and job satisfaction is consistently correlated in determining the potential and performance of a task (Jacqueline, 2005). A research on professional salespeople has supported this relationship and it has shown that employees who are tenacious and efficient are capable of carrying out their duties and achieve job satisfaction in their work accordingly (Michael, 2010). The effectiveness of self-efficacy on job satisfaction will increase if the employers are able to meet the employees' needs (Lauren, 2010).

In addition, the researcher is prompted to investigate the roles of autonomy in the relationship between self-efficacy and job satisfaction among employees because autonomy also influenced the behavior, intrinsic motivation and efficiency of the workers (Peter et al, 2003; Michael et al, 2013; Naqvi et al, 2013). Autonomy is defined as a freedom given to someone to use their own knowledge and to determine, select and control work schedule according to capabilities (Myung et al, 2012). The integration of freedom and autonomy is a positive working experience that has a major influence in organizing tasks, working methods and it is predicted to moderate job satisfaction (Einar et al, 2014; Anh et al, 2003)

\subsection{Objectives of the Study}

The research objectives are as follows;

1. To identify the impact of Personality Big Five dimensions on job satisfaction among employees.

2. To identify the impact of Personality Big Five dimensions on self-efficacy among employees.

3. To identify the impact of self-efficacy on job satisfaction among employees.

4. To identify the impact of self-efficacy as mediator between Personality Big Five dimensions and job satisfaction among employees.

5. To identify the impact of autonomy as moderator between self-efficacy and job satisfaction among employees.

\subsection{LITERATURE REVIEW}

\subsection{Job Satisfaction}

Job satisfaction is defined as the positive emotional state of one's work experience or the pleasure of working (Klaus, 2012). The determinant of job satisfaction is subjective and does not only depend on the nature of the job but also the perception and one's evaluation (Chang et al, 2010). Jamie (2009) has studied on the work environment and job satisfaction affirmed that employees are the main success in an organization. Employees who are committed, confident and achieved job satisfaction are making significant contribution to the organization. Even, positive attitude also plays an important role which may leads to mutual help, cooperation and respect with coworkers to provide better quality services. Job satisfaction is the significant construct in organizational behaviour and psychology research which relates to individual's personality, outcomes and direct impact on one's work environment (Judge et al, 2002; Chang et al, 2010). Besides, it present implications and levels of individual or organization's behavior which happens to show the quality of life at work and the main determinant for maintaining the organization's employees (Chang et al, 2010; Lottie, 2013).

Job satisfaction is a key component in individual's life which positively influence efficiency, performance and outputs. Most studies in occupational research normally focus to investigate in working conditions, job specifications, and relationships in workplace, job schedules, job security, responsibility, promotion, remuneration, leadership styles and organizational policies. Previous studies has shown that job satisfaction improved individual's personality, outcomes, direct impact on one's work environment, quality of life and can avoid frustration, demotivated, decreased work performance and turnover (Chang et al, 2010; Jusuf, 2012; Lottie, 2013). Oyewumi et al, (2012) 
stated that in education context, employees who achieve job satisfaction able to provide good service for students and contribute to world ranking university (Edward et al, 2009).

On the other hand, Herzberg (1966) has developed Two Factor Theory which is useful to measure hygiene and motivator factors in job satisfaction. Job satisfaction is divided into internal features of the intrinsic (skills, job control, responsibility, challenge) and external features of extrinsic (salary, working conditions, relationships, security, conditions of employment). Both features are related positively to job satisfaction and influences individual's life, efficiency, performance, outputs and as an instrument associated with the work (Cohrs $e t$ al, 2006; Chang et al, 2010; Peter et al, 2003). Individually, job satisfaction influenced personality characteristics, reflects the attitude, affective evaluation of employee's satisfaction in determining employee commitment to the task, quality of service, working experience thus leads to organizational performance in future (Aikaterini et al, 2014). Employee, who achieved job satisfaction, tends to become more effective, productive, showed positive attitudes and emotions in profession and organization (Naqvi et al, 2013). Previous studies have shown positive relationship between employee's behavior and job satisfaction (Edward et al, 2009; Cohrs et al, 2006; Ismail, 2012). Thus, the findings have urged the employers to develop effective strategies on employee job satisfaction and to enhance positive working behavior (Homa et al, 2014).

\subsection{Personality Big Five}

Numerous studies have proved that employees behaved according to their own personality. Understanding employee's personality is vital to provide helpful information on how employee reacts in different situations (Heidi, 2012). Employee's personality is seen as a universal form, appears as a unique combination of concrete, positive and negative impacts (Ferguson, 2009). In this study, Personality Big Five is selected because it is often used to predict a person's behavior (Hui-Fang, 2007). Accordingly, Personality Big Five has provided the basic characteristics of the construction of self that says each individual has a level of consistency and differences themselves. Personality Big Five refers to an individual's consistent patterns of thought and attitude (Adrian et al, 2009). Personality Big Five also refers to individual's emotion in interaction and effective communication in response of work events or work conditions (Gellatly et al, 2001).

In this study, Personality Big Five model will be used to predict a person's behavior (Heidi, 2012). Personality Big Five is an adaptable structure across culture, measurable and use as references (Isabel et al, 2013). This model classified five dimensions that are increasingly popular with the acronym OCEAN (openness, conscientiousness, extraversion, agreeableness, neuroticism) to describe individual differences. Furthermore, Personality Big Five dimensions were consistently associated with job satisfaction and each dimension refers to the aspect of individual personality (Hui-Fang, 2007) which consists of five dimensions; i) openness relates to individual who is imaginative, understanding, curiosity, sensitive, high potential, intellectual and open-minded, ii) neuroticism relates to individual who is emotionally unstable, has unpleasant thoughts and distractions, iii) agreeableness relates to individual who are helpful, simple, generous and sympathy, iv) conscientiousness relates to individual who is hardworking, active, committed, consistent, responsible, organized, systematic and efficient, and v) extraversion relates to individual who is optimistic and sociable.

Personality Big Five is often used in studies associated with job satisfaction (Heidi, 2012). Besides, this model is user-friendly, easy to understand and is able to determine the relevance of personality and personal achievement on a global level (Rita, 2000). Each personality trait will show individual's uniqueness, ability and differences in achieving own personal goal, improve performance and adaptation to society (Homa et al, 2014). The model of Personality Big Five has gained great interest in determining the level of self-job satisfaction at the global construct level (Kyle, 2012; Daniel et al, 2002). Some aspects of the personality and each stage personality have provided relevant information, even plays an important role influencing each individual to succeed in achieving job satisfaction (Azizi et al, 2012).

Previous studies have shown positive relationship between Personality Big Five dimensions and job satisfaction such as Judge et al, (2002) studied on 163 independent samples and Michael (2010) researched on 51 employees in Kansas has proved similar results that dimension of conscientiousness and agreeableness are significant predictors on job satisfaction. In In addition, other dimensions such as extraversion is correlatedly positive in a variety of jobs among executives (Seibert et al, 2001; Vivian, 2005; Zimmerman, 2008; Heidi, 2012), openness is related with mastery training (Heidi, 2012), whereas neuroticism has a negative relationship with job satisfaction due to its unstable thoughts and distractions in completing tasks (Heidi, 2012).

The importance to investigate the relationship between Personality Big Five dimension and job satisfaction has revealed that dispositional tendency of personality differences were significantly and extrinsically consistent with job satisfaction (Jamie, 2009). Klaus (2012) confirmed the relationship between Personality Big Five dimensions and job satisfaction on 354 employees from 12 organizations in Singapore and Daniel et al, (2002) studied on 153 university employees from various professions. The findings have shown a significant correlation between Personality Big Five dimensions and job satisfaction. In conclusion, Personality Big Five is useful in the field of organizational psychology and education, has strength in making positive contribution to better understanding individual's personality differences, has validity and reliability in predicting the relationship between personality and job satisfaction (Heidi, 2012).

\subsection{Self-Efficacy}

Self-efficacy has been growing in modern organizations and by adding its effect on job satisfaction, self-efficacy seen as a cognitive mechanism that control one's behaviour, influencing feelings, ways of thinking, ability in implementing and managing tasks effectively (Rita, 2000). Self-efficacy influences individual's actions intrinsically and extrinsic in decision-making, work-related problems and goal setting (Sven, 2008). Self-efficacy has an impact on attitude, making judgments wisely enhance individual's work performance in a variety of ways include mastering difficult and challenging tasks (Aikaterini et al, 2014). Self-efficacy is a self-development that contributes to high commitment and achievements, able to reduce depression, stress and failures (Oyewumi et al, 2012). An individual with high self-efficacy is independent, smart in controlling and commanding, efficient in addressing his tasks, comfortable in his jobs, able to overcome pressures in work and able to achieve organizational goals (Rita, 2000; Judge et al, 2002). 
According to Bandura (1982), self-efficacy is generally defined as the judgment of 'how well one can execute courses of action required dealing with prospective situations' and can be altered by behaviour, internal personal factors in the form of cognitive, affective, biological events and external environment. Self efficacy is also defined as the beliefs in one's own capabilities, level of motivation and actions to perform in various situations, thus can be serving as a potential mediator in human agency and a major basis for action. Self-efficacy is strongly related to actual and future career performance, capability to perform well in a given situation or encounter effectively. Furthermore, self-efficacy has been linked to such important occurrences as the selection of goals, effort expenditure, task persistence, affective experiences and the worth of one's analytical cognitive performance. The ability to achieve goals is likely to result in the realization of one's objectives, the development and exercise of personal control using their skills successfully (Amna et al, 2012).

On the other hand, Social Cognitive Theory (SCT) is useful to explain self-efficacy or human self-development individually (Lent $e t$ al, 2006). Bandura (1986) has developed Social Cognitive Theory (SCT) in determining behaviour that is consistent compared from other constructs. The theory is used to explain human behaviour that consists of three factors including behaviour, personal and environmental which affects each other. SCT describes one's perception of their ability to cope with diverse challenges, refrain or pursue certain behaviours (Robert et al, 2008). According to Sven (2008), SCT involves learning and interaction behavior of individuals in private with biological and environmental factors. SCT influences actions, feelings, thoughts and beliefs of individuals to react. This reaction formed self-efficacy in performance of duties and enhance efforts in dealing with stress and adversity to achieve. In addition, self-efficacy is the belief and confidence to achieve something intentionally. Individuals have personal goals and thoughts of the future to achieve results. The individual will plan the strategy, structure and behavior of action to achieve the goal. This can be achieving through ongoing commitment with their task and social learning. Social learning is an individual cognition in social environment to reinforce their abilities in work and is also known as self-efficacy (Sven, 2008).

In SCT, self-efficacy is the influence of internal self-control and regulated continuously, which operates in monitoring the behavior itself include the determining factor, reaction, impact on the environment as well as self-affective. A regulation of self-control is an important role of thoughts, actions and self-motivation which has been linked to such important occurrences as the selection of goals, effort expenditure, task persistence, affective experiences and the worth of one's analytical cognitive performance. Significantly, the ability to achieve goals is likely to result in the realization of one's objectives, the development and exercise of personal control using their skills successfully. Thus, SCT is helpful in explaining self-efficacy together with personality and job satisfaction which is consistent with current research (Robert et al, 2008).

According to Jacqueline (2005) self-efficacy is formed since childhood and grew with age after going through a variety of situations, experiences, skills, understanding and assignments. Self-efficacy will increase each time the assignment was successfully completed and is strongly influences on the locus of control, behavior's control, effort and motivation to succeed, consists of four sources, namely; i) mastery experiences - dominate the experience to strengthen self-efficacy when dealing with challenging assignments, ii) social modeling continuously monitor a person's success will instil and effort to also do the same until succeed, iii) social persuasion - a positive persuasion or encouragement for someone to make him believe own ability and skills to succeed in his job. This helps the individual to overcome self doubt and focus on the task better, iv) psychology responses - own emotional reactions to certain situations and how to react self-efficacy on stress, challenges and difficult tasks.

In the organization, self-efficacy is an important and effective predictor to evaluate employee job satisfaction, bring implications for the recruitment and retention of employees (Hui-Fang, 2007). The relationship between self-efficacy and job satisfaction is correlately consistent in determining the potential and performance of a task (Jacqueline, 2005). A research on professional salespeople has supported this relationship and shown that employees who are tenacious and efficient are capable of carrying out their duties and achieve job satisfaction in their work accordingly (Michael, 2010). The effectiveness of self-efficacy on job satisfaction will increase if the employer able to meet the employees' needs (Lauren, 2010). Self-efficacy will be increased from time to time to solve the problem (Homa et al, 2014). The level of self-efficacy increased is parallel with the increase of job satisfaction. Once the problem is resolved, the risk and stress of work will decreases thus job satisfaction will be achieved. This will benefit the employer in order to maintain employee commitment, organizational performance and job satisfaction (Aikaterini et al, 2014).

Other than that, in predicting the effectiveness of employee's self-efficacy on job satisfaction, Lauren (2010) has investigated on 101 adults and Liao et al, (2008) studied on 485 respondents from government departments and private companies in China also proved that job satisfaction will increase if self-efficacy is deeply recognized, hence assist them to improve their efficiency.

\subsection{Autonomy}

Autonomy is defined as independence in controlling over work methods, personal initiative in scheduling daily work activities and own standards in determining working performance individually (Myung et al, 2012). Scheduling of work involved in controlling the level of work activities and modifying a standard of performance (Blossom et al, 2011). Autonomy encourages employees to think independently when responding to the challenges and problems of work. Autonomy also emphasizes a sense of responsibility, establishes job skills, emergence of self-efficacy and associated with job satisfaction in organizations (David et al, 2001; Carlos et al, 2012). Besides, autonomy enhance personal development and self-help employees in planning, setting, decides own careers, integrate more functions and role in the organization (Chia et al, 2013). The integration of freedom and autonomy is a positive working experience that influential in organizing tasks, working methods and job satisfaction (Einar et al, 2014).

In this study, Self-determination Theory (SDT) is selected because it has the elements of autonomy that foster personal development and lead to job satisfaction (Adalgisa et al, 2013). SDT is a macro theory associated with motivation and focus on self-determined behavior (Visser, 2010). Edward et al, (2008) stated that SDT is an empirical theory that describes self-development and human safety. Roger (2013) explained that SDT is a motivation approach of individual's behaviour, personal factors and social environment which affects the autonomy of employees to work independently without supervision. SDT describes intrinsic motivation which drives performance and predicts job satisfaction. Intrinsic motivation associated with autonomy control which initiates the individual to respond positively to the challenges of work. Challenges in work will contribute to high competence in work performance and external support enhances satisfaction (Michael et al, 2013). 
SDT consists of three elements; i) autonomy refers to the desire to set their own actions independently, ii) competence refers to the desire to be able to affect the environment and iii) relatedness refers to the desire associated with the social group. SDT explained that the elements of autonomy is important in improving own work setting, control own actions to produce effective outcomes and healthy behavior. SDT also stressed on the relevant virtues of autonomy in optimal working efficiency. Autonomy consistently increases energy of self-regulation. Other than that, SDT outlines the concept of individual differences and strengths compared to other individuals in life goals that dominate their work. Eventually, individuals have their own principles without others influence, feature positive behavior with a sense of responsibility, foster personal development and lead to job satisfaction to meet the organization's goals (Edward et al, 2008). Previous studies on 3,973 government employees in 18 countries of Europe have also proven that autonomy able to promote job satisfaction (Myung et al, 2012).

\subsection{HYPOTHESES DEVELOPMENT}

Job satisfaction can be conceptualized as a function of working conditions that depends on various factors including Personality Big Five (Cohrs et al, 2006). Personality Big Five is a positive predictor that strongly supported job satisfaction (Daniel et al, 2002; Klaus, 2012; Chang et al, 2010; Adrian et al, 2009; Joyce et al, 2003). The importance of the relationship between Personality Big Five and job satisfaction is overwhelming in organizational psychology (Nikos, 2004). The positive influence of Personality Big Five on job satisfaction has revealed employee's behavior towards his work quality, innovative, behavior in learning new skills and performance (Adrian et al, 2009; Jamie, 2009).

According to Heidi (2012) Personality Big Five have shown consistently that each of his dimensions has positive influenced on job satisfaction. This has been demonstrated by Vivian (2005) who studied on 5,932 employees in the United States and indicated that employees who have a positive attitude towards work are able to achieve job satisfaction. Meanwhile, other psychologists have proved that several dimensions are positive on job satisfaction such as Klaus (2012) studied on 354 head of departments from 12 organizations in Singapore and discovered only dimension of conscientiousness, extraversion, agreableness and neuroticism were significant with job satisfaction. Whereas, Michael et al, (2006) reviewed on 141 customer service employees at fast food stores in the United States and proved that dimension of extraversion, agreableness and neuroticism were positive with job satisfaction.

Besides, Cheng-Liang et al, (2014) also studied on 360 workers from 31 financial organizations in Taiwan have discovered only dimension of extraversion was positive with job satisfaction, whereas the dimensions of openness, conscientiousness, agreableness and neuroticism were negative with job satisfaction. In addition, Cohrs et al, (2006) studied on 1,065 professional employees in Germany discovered only dimension of neuroticism was positive on job satisfaction. Chang et al, (2010) studied on 314 nurses from two hospitals in Taiwan has shown positive relationship between personality traits and job satisfaction, thus proved the important of Personality Big Five dimensions in evaluating job satisfaction. This indicates that job satisfaction is not only related to extrinsic factors but is also associated with personality differences. Although the work involved norms and obligations, personality traits still affect employee's expectation or perception to achieve higher job satisfaction (Chang et al, 2010; Klaus, 2012). Based on the previous studies indicated that differences in personality traits and interaction with job satisfaction is useful in explaining an individual working conditions. Thus, the following hypotheses have been established;

Ha1: The dimension of openness will correlate positively with job satisfaction among employees.

$\mathrm{Ha}_{2}$ : The dimension of conscientiousness will correlate positively with job satisfaction among employees.

Ha3: $\quad$ The dimension of extraversion will correlate positively with job satisfaction among employees.

Ha4: The dimension of agreeableness will correlate positively with job satisfaction among employees.

Has: The dimension of neuroticism will correlate negatively with job satisfaction among employees.

Apart from Personality Big Five model is used to predict the individual's behavior on job satisfaction, there are other factor that supported known as self-efficacy (Felissa, 2004). Hui-Fang (2007) emphasized that Personality Big Five is a personal trait, thinking, behavior and emotion that is related with self-efficacy. This was supported by Rita (2000) who studied on 131 trainees at Northern Arizona University, USA and proved that self-efficacy is positively associated with job satisfaction, whereas the dimension of agreeableness plays an important role to increase the level of self-efficacy. The findings assist in understanding the role of self-efficacy and its effectiveness in organisation.

Carlos et al, (2012) investigated on 266 bank employees in Portugal and discovered that the dimension of openness is positively correlated with self-efficacy, thus proved that self-efficacy influenced employee's satisfaction and will increase high remuneration in the organization. In addition, Byunghwa et al, (2011) studied on 980 insurance' employees in South Korea and indicated that the dimensions of extraversion and conscientiousness are positive with self-efficacy. The differences in personality traits will affect self-efficacy and understanding it will assist the organization to provide training or programs for employee. This statement is supported by Sven (2008) who studied on 356 professionals in the UK that dimension of agreeableness and extraversion able to predict employee's self-efficacy.

Other than that, self-efficacy is a specific domain that is useful to understand the individual's behavior and work activity. This statement was supported by Gary et al, (2011) who investigated on 157 people in the US and discovered that dimension of conscientiousness was positive with self-efficacy. Whereas, Hui-Fang (2007) who studied on 428 workers in Taiwan fitness center indicated that Personality Big Five dimensions were positive with self-efficacy. The findings suggested that self-efficacy is important in exploring and enhancing the individual's ability to focus and believe what they can accomplish. Based on the statements, self-efficacy is an important variable that will produce the desired results. Therefore, the following hypotheses are developed;

Ha6: $\quad$ The dimension of openness will correlate positively with self-efficacy among employees.

Ha7: The dimension of conscientiousness will correlate positively with self-efficacy among employees.

Has: The dimension of extraversion will correlate positively with self-efficacy among employees. 
Ha9: The dimension of agreeableness will correlate positively with self-efficacy among employees.

Ha10: The dimension of neuroticism will correlate negatively with self-efficacy among employees.

According to the Social Cognitive Theory, self-efficacy is the best predictor and a catalyst for positive change in job satisfaction (Laura et al, 2010). Therefore, self-efficacy variables should be included in this study and these statements are supported by Jennifer et al, (2009) and Nicola (2014). According to Melisa (2013) self-efficacy provides many benefits in upgrading skills, efficiency, tenacity, setting goals, making appropriate planning and sustainable strategy for the organization. In the process of learning and improvement of individual skills, self-efficacy acts as predictor that is capable of detecting any occurrence of complexity behavior and capable to determine future actions or long-term outcomes for the organization (Scholz et al, 2005).

Jacqueline (2005) investigated on 160 professors at Ohio State University, USA and Allison (2009) studied on 137 psychology doctors at the community center, US and both studies have shown that self-efficacy positively affect job satisfaction. They concluded that employees who have high self-efficacy will continue to work successfully and associate the success within them. In other words, the increment of self-efficacy is parallel with the increment of personal achievement or satisfaction. Therefore, this indicates that employees, who have high self-efficacy, work harder and able to achieve job satisfaction consistently. In addition, Jamie (2009) has reviewed over 184 hotel workers in south Florida; the United States proved that self-efficacy had a positive impact on job satisfaction. He said when job satisfaction increased; individuals have a level of competence and confidence in his work, whereas individual with high self-efficacy showed that he is capable of handling challenges for a better performance. Therefore, self-efficacy is associated with a strong impact of behavior and ability in work satisfaction (Jamie, 2009).

According to Ulfiani et al, (2014) who conducted a study on 208 teachers in South Sulawesi, Indonesia stated that self-efficacy is positively associated with job satisfaction. This implies that self-efficacy is a virtue in carrying out the work successfully, influenced individual's thought and behavior in decision making. This is supported by Mustafa et al, (2012) who investigated on 161 accountants in Turkey that the combination of self-efficacy and job satisfaction will increase the level of individual's confidence and ability in completing a task. Comprehending the role of self-efficacy and job satisfaction in increasing individual's satisfaction, were proven by Ming-Cheng et $a l$, (2012) who studied on 616 car salesman in Taipei, Taiwan and Yuhsuan et al, (2015) on 314 nurses in northern hospital, Taiwan. Both studies have shown that self-efficacy has a positive significant on job satisfaction and the findings will assist the organization to improve management policies in maintaining organization's performance.

The potency of self-efficacy has been exposed by Sandra et al, (2013) who studied on 108 employees of real estate in Victoria, Australia and proved that self-efficacy had a positive impact in work performance, hence concluded that individual with high self-efficacy is capable to control negative emotions such as stress and does not depend on colleagues to achieve job satisfaction. According to Laura et $a l$, (2010) who investigated on 1,172 respondents in Rome, Italy have shown that self-efficacy is positively related to job satisfaction, thus controlled individual's work behavior, attitude, achievement, performance and satisfaction. This also implies that individual's with high self-efficacy is confidence, efficient and inclined towards challenging task in the future, thus formed the hypotheses below;

Ha11: There is a significant impact of self-efficacy on job satisfaction among employees.

On top of that, the role of self-efficacy as a mediator between Personality Big Five and job satisfaction will be further explored. According to Mary et al, (2007) and Joyce et al, (2003), self-efficacy has the potential as mediator and promotes the individual's ability to perform effectively. Byunghwa et al, (2011) studied on 980 employees at the largest insurance companies in South Korea have shown that self-efficacy is a significant mediator in the relationship between dimension of conscientiousness, extraversion and work performance, thus establised a dynamic behavior to achieve higher satisfaction.

Besides, Susanti (2011) investigated on 190 bank employees in Indonesia has proved that self-efficacy is a significant impact as a mediator between autonomy and job satisfaction, whereas Peter et al, (2003) who studied on 161 job applicants in the Netherlands have found that self-efficacy is a significant mediator in the relationship between the dimension of extraversion, neuroticism and job satisfaction. Both studies indicated that self-efficacy is a predictor and has significant impact as a mediator among variables. The effectiveness of self-efficacy as a mediator has been proved also by Cohrs et al, (2006) who studied on 1,065 professional workers from three samples in Germany and proved that self-efficacy is an effective mediator in the relationship between the dimension of neuroticism and job satisfaction. This confirmed the ability of self-efficacy as a mechanism or mediator to increase job satisfaction. Therefore, the hypotheses are established;

Ha12: There is a significant impact of self-efficacy as mediator between Personality Big Five dimension of openness to experience and job satisfaction among employees.

Ha13: There is a significant impact of self-efficacy as mediator between Personality Big Five dimension of conscientiousness and job satisfaction among employees.

Ha14: There is a significant impact of self-efficacy as mediator between Personality Big Five dimension of extraversion and job satisfaction among employees.

Ha15: There is a significant impact of self-efficacy as mediator between Personality Big Five dimension of agreeableness and job satisfaction among employees.

Ha16: There is a significant impact of self-efficacy as mediator between Personality Big Five dimension of neuroticisim and job satisfaction among employees.

Other than that, the influnce of self-efficacy as a mediator in the relationship between Personality Big Five and job satisfaction, the role of autonomy as a moderator in the relationship between self-efficacy and job satisfaction will also explored. According to Chia et al, (2013), autonomy will assist an individual or employee to have confidence in performing his tasks better. The investigation on 383 lectures at universities in Kuala Lumpur, Perak and Penang has proven that autonomy is an intrinsic motivation that related with self- 
efficacy and work performance to establish a competitive work situation. Employees who are provided autonomy attained their freedom to work flexibly and creatively, thus will increase job satisfaction (Carlos et al, 2012). Similarly, Susanti (2011) who studied on 190 bank employees in Indonesia has proved that autonomy had a positive impact on job satisfaction in which the increment level of autonomy and job satisfaction are parallel. This statement was supported by Naqvi et al, (2013) who studied on 107 employees at a famous fast food restaurant in Pakistan and Anh et al, (2003) who used data from the National Education report (NELS2000) for 5 consecutive years in England, have shown that autonomy has increased the level of employees commitment and initiative in their work, thus concluded that autonomy is a significant determinant of job satisfaction.

In addition, Peter et al, (2013) studied on 165 construction employees in petroleum retail companies, Singapore indicated that autonomy promotes job satisfaction. Similar studies by Carlos et al, (2012) on 266 bank employees in Portugal have shown that strengthen the positive effect of autonomy will increase the effectiveness of self-efficacy. This statement was also supported in previous studies, such as David et al, (2001) on production employees in the United States; Blossom et al, (2011) on 1,380 community health center employees in Taiwan; and Myung et al, (2012) on 3,973 government employees in 18 countries of Europe have also proven that autonomy able to promote job satisfaction.

According to Einar et al, (2014) autonomy and self-efficacy is related with motivation and emotion towards job satisfaction. He has investigated on 2,569 primary and secondary school teachers in Norway and confirmed that autonomy, and self-efficacy is universal needs that have a positive impact on job satisfaction. This statement is supported by Roger (2013) who studied on of 1,818 principals in Norway and also stated that autonomy and self-efficacy has a significant impact on job satisfaction. These findings have provided information that employees who believe in their own ability and competences are able to perform their duties competently and achieve job satisfaction. The combination of autonomy and self-efficacy will contribute to employees' motivation, commitment, wellness and satisfaction, thus they are capable in controlling the work environment and overcome work constraints. Therefore, the hypotheses are established;

Ha17: There is a significant impact of autonomy as moderator between self-efficacy and job satisfaction among employees.

\subsection{THEORETICAL MODEL}

In order to achieve the objectives of this study, the proposed research model is depicted in Figure 1 . The independent variable is Personality Big Five dimensions and self-efficacy has been selected as the mediating variable where it mediates the relationship between Personality Big Five dimensions and job satisfaction. In addition, autonomy is the moderating variable where it moderates the relationship between self-efficacy and job satisfaction.

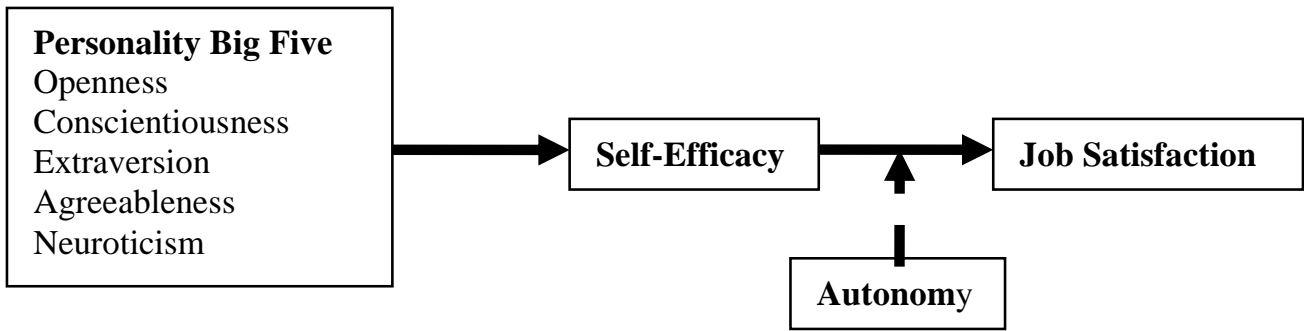

Figure 1 Theoretical framework

\subsection{CONCLUSION}

The importance of job satisfaction in Malaysia has become main highlight in relation of employee's performance and satisfaction. Employee who achieved job satisfaction will increase organizational performance and productivity (Zainudin et al, 2010). Employee's who attain satisfaction will avoid negative impact in role ambiguity or role conflict, lead to transformation of quality, efficient, committed, dedicated, valuable and become knowledgeable employees (Carlos et al, 2012). Several studies are sought to conduct the research on job satisfaction in the organisation (Oyewumi et al, 2012). Job satisfaction has become a priority for the organisation to enhance employees' performance. This study will identify the importance of job satisfaction in employees and to further explore the impact Personality Big Five dimensions, self-efficacy and autonomy on job satisfaction. The results of this study will be a useful contribution and practiced to the organization. (Edward et al, 2009).

Theoretically, this study will propose a framework to the organization and as a source of references for future studies. The study conducted also has some interests that will hopefully benefit related parties such as identifying the role of employer to help employees achieve excellence in performance, assist university in raising employees' satisfaction and identifies personality dimensions, self-efficacy and autonomy effectively in the employees' working process (Heidi, 2012). The organization can develop self-building programs and employee evaluation from time to time to enhance positive working behaviour and contribute to knowledgeable employees (Byunghwa et 
al, 2011). The individual differences of Personality Big Five, self-efficacy and autonomy in job satisfaction will reveal different results which is beneficial for employees to increase awareness and participation in their own working environment, improve strategies and motivational methods to improve job satisfaction (Einar et al, 2014).

\section{References}

Adrian Furnham, Danreas Eracleous \& Tomas Chamorro-Premuzic. (2009). Personality, Motivation and Job Satisfaction: Hertzberg Meets The Big Five. Journal Of Managerial Psychology, 24(8), 765-779.

Aikaterini Gkolia, Dimitrios Belias, Anthanasios Koustelios. (2014). Teacher's Job Satisfaction and Self-Efficacy: A Review. European Scientific Journal, 10(22).

Allison M. Herlickson. (2009). The Differences In Levels Of Job Satisfaction Burnout and Self-Efficacy Between Correctional and Community Psychologists: The Effect Of Personality Dan Work Environment. MI. Proquest LLC.

Amna Yousaf and Karin Sanders. (2012). The Role Of Job Satisfaction and Self-Efficacy As Mediating Mechanisms In The Employability and Affective Organizational Commitment Relationship: A Case From A Pakistani University. Thunderbird International Business Review, 54(6).

Anh Ngoc Nguyen, Jim Taylor and Steve Bradley. (2003). Job Autonomy and Job Satisfaction: New Evidence. JEL Classification, I31, J28.

Azizi Yahaya, Noordin Yahaya, Abdul Talib Bon, Sharifuddin Ismail, Norzana Mohamed Noor. (2012). The Relationship Between Big Five Personality With Work Motivation, Competitiveness and Job Satisfaction. Elixir Psychology, 44 (2012) 7454-7461.

Bandura, A. (1986). Social Foundations of Thought dan Action: A Social Cognitive View. Englewood Cliffs, NJ: Prentice-Hall.

Blossom Yen-Ju Lin, Yung-Kai Lin, Cheng-Chieh Lin, Tien-Tse Lin. (2011). Job Autonomy, Its Predispositions and Its Relation To Work Outcomes In Community Health Centers In Taiwan. Health Promotion International, 28(2).

Byunghwa Yang, Youngchan Kim \& Richard G. McFarland (2011). Individual Differences and Sales Performance: A Distal-Proximal Mediation Model of SelfEfficacy, Conscientiousness, and Extraversion. Journal of Personal Selling \& Sales Management, 31:4, 371-381.

Carlos M.P.Sousa, Filipe Coelho, Encarna Guillamon-Saorin. (2012). Personal Values, Autonomy and Self-Efficacy: Evidence From Frontline Service Employees. International Journal of Selection dan Assessment, 20(2).

Chang Y.H., H.H. Li, C.M. Wu \& P.C. Wang. (2010). The Influence Of Personality Traits On Nurses' Job Satisfaction In Taiwan. International Nursing Review, 478484.

Cheng-Liang Yang Mark Hwang. (2014). Personality Traits And Simultaneous Reciprocal Influences Between Job Performance And Job Satisfaction. Chinese Management Studies, 8, 6-26.

Chia Choo Seng, Chong Su Theng, Lee Suet Ling, Tan Thye Siang, Wan Bao Yean. (2013). The Effect Of Big Five Personality On Job Performance: Job Autonomy As The Moderator. UNITAR Theses.

Cohrs J. Christopher, Andrea E. Abele \& Dorothea E. Dette. (2006). Integrating Situational and Dispositional Determinants of Job Satisfaction: Findings From Three Samples of Professionals. The Journal of Psychology: Interdisciplinary and Applied, 140:4, 363-395

Daniel Heller, Timothy A. Judge \& David Watson. (2002). The Confounding Role Of Personality and Trait Affectivity In The Relationship Between Job and Life Satisfaction. Journal Of Organizational Behavior, 23, 815-835.

David W.Denton, Lawrence S.Kleiman. (2001). Job Tenure As A Moderator Of The Relationship Between Autonomy and Satisfaction. Applied H.R.M.Research, 6(2), $105-114$.

Edward L.Deci and Richard M.Ryan. (2008). Self-Determination Theory: A Macrotheory Of Human Motivation, Development Dan Health. Canadian Psychology, 49(3), 182-185.

Edward Sek Khin Wong, Teoh Ngee Heng. (2009). Case Study of Factors Influencing Jobs Satisfaction in Two Malaysian Universities. International Business Research, 2(2).

Einar M.Skaalvik dan Sidselskaalvik. (2014). Teacher Self-Efficay and Perceived Autonomy: Relations With Teacher Engagement, Job Satisfaction and Emotional Exhaustion. Psychological Reports: Employment Psychology \& Marketing, 114(1), 68-77.

Fauziah Noordin \& Kamaruzaman Jusoff. (2009). Levels of Job Satisfaction amongst Malaysian Academic Staff. Asian Social Science, 5(5).

Felissa K. Lee. (2004). Conscientiousness, Neuroticism, Dan Self-Management Strategies: A Process Model Of Personality and Achievement Outcomes. ProQuest Information dan Learning Company. US.

Ferguson, Harvie. (2009). Self; Identity and Everday Life Database: Ebook Collection (Ebscohost). 224.

Gary N. Burns And Neil D. Christiansen. (2011). Self-Efficacy In The Workplace: Linking Personality To Domain-Specific Efficacy Beliefs. International. Journal Of Selection And Assessment, 19(4).

Gauri S.Rai. (2013). Job Satisfaction Among Long-Term Care Staff: Bureaucracy Isn’t Always Bad. Administration in Social Work, $37(1)$, 90-99.

Gellatly IR \& Irving PG. (2001). Personality, Autonomy and Contextual Performance Of Managers. Human Performance, 14(3), 2321-245.

Heidi Nguyen.(2012). A Quantitative Study Of Relationships Between Demographic Characteristics, Personality, and Job Satisfaction Among Information Technology Personnel In Ho Chi Minh City, Vietnam. ProQuest LLC.

Homa Khorasani Esmaeili, Hamed Tahsildari, Mohd Taib Hashim \& Rosmini Omar (2014). The Concurrent Role of Personality Traits and Self-Efficacy on Employees' Work Satisfaction: A Review. Interdisciplinary Journal Of Contemporary Research In Business, 5, 11.

Hui-Fang Lee. (2007). The Relationships Among Personality Traits, Self-efficacy and Organizational Commitment In Fitness Center Staff. Proquest Information and Learning Company

Ismail Hussein Amzat \& Datuk Abdul Rahman Idris. (2012). Structural Equation Models Of Management Dan Decisionmaking Styles With Job Satisfaction Of Academic Staff In Malaysian Research University. International Journal of Educational Management, 26(7), 616-645

Jacqueline Ellenor Lamuth. (2005). A Comparison Of Formal and Non-Formal Managers Within Ohio State University Extension: An Examination Of Self-Efficacy, Training Choices, and Job Satisfaction. Proquest Information and Learning Company

Jamie J. Bodouva. (2009). The Influence Of Employee Perceptions Of The Work Climate On Perceived Service Quality and Their Relationships With Employee Goal Orientations, Employee Self-Efficacy and Employee Job Satisfaction. Proquest LLC.

Jennifer A. Rooney, Benjamin H. Gottlieb and Ian R. Newby-Clark. (2009). How Support-Related Managerial Behaviors Influence Employees. An Integrated Model. Journal Of Managerial Psychology, 24(5), 410-427.

Joyce E. Bono \& Timothy A. Judge. (2003). Core Self-Evaluations: A Review Of The Trait and Its Role In Job Satisfaction and Job Performance. European Journal Of Personality, 17, 5-18.

Judge, T. A., Heller, D., \& Mount, M. K. (2002). Five-Factor Model Of Personality And Job Satisfaction: A Meta-Analysis. Journal Of Applied Psychology, 87(3), $530-541$.

Jusuf R.H.Hasibuan. (2012). Pengaruh Kualitas Kerja \& Kepuasan Karyawan Terhadap Kepuasan Pelanggan Pada TB. Gramedia Di Kota Palembang. Jurnal Manajemen Pemasaran.

Klaus J. Templer. (2012). Five-Factor Model Of Personality and Job Satisfaction: The Importance Of Agreeableness In A Tight and Collectivistic Asian Society. Applied Psychology, 61 (1), 114-129.

Kyle Garret Mack. (2012). Conscientiousness As A Moderator Of The Relationship Between Work Autonomy and Job Satisfaction. Proquest LLC.

Lauren Michel Orozco. (2010). An Empirical Comparison Between The Neo-FFI Dan The WPI Dan The Relationship Between Self-Efficacy and Workplace Personality. Proquest LLC.

Laura Borgogni , Silvia Dello Russo, Laura Petitta \& Michele Vecchione (2010). Predicting Job Satisfaction and Job Performance in a Privatized Organization International Public Management Journal, 13:3, 275-296. 
Lent, R. W., \& Brown, S. D. (2006). Integrating Person and Situation Perspectives On Work Satisfaction: A Social-Cognitive View. Journal of Vocational Behavior, 69(2), 236-247.

Liao S, WC Fei, CT Liu. (2008). Relationships Between Knowledge Inertia, Organizational Learning and Organization Innovation. Technovation, (28)4, 183-195. Lottie P.Beebee. (2013). A Model of Teacher Retention. The Interelationships of Job Satisfaction, Professional Learning and Collective Efficacy. ProQuest LLC.

Mary S. Logan \& Daniel C. Ganster. (2007). The Effects Of Empowerment On Attitudes and Performance: The Role Of Social Support and Empowerment Beliefs. Journal Of Management Studies, 44(8).

Michael D.Carr \& Phil Mellizo. (2013). The Relative Effect Of Voice, Autonomy, and The Wage On Satisfaction With Work. The International Journal of Human Resource Management, 24:6,1186-1201.

Michael H. Katz. (2010). Job Satisfaction As Influenced By The Big Five Personality Traits. Proquest LLC.

Michael Gabriel Frino. (2010). Self-Efficacy and Job Satisfaction As Predictors Of Successful Performance Of Sales Professionals In Business-To-Business Sales Organizations. Proquest LLC.

Ming-Cheng Lai and Yen-Chun Chen. (2012). Self-Efficacy, Effort, Job Performance, Job Satisfaction and Turnover Intention: The Effect of Personal Characteristics on Organization Performance. International Journal of Innovation, Management and Technology, $3,4$.

Mustafa Yakin \& Oya Erdil. (2012). Relationships Between Self-Efficacy and Work Engagement and the Effects on Job Satisfaction: A Survey on Certified Public Accountants. Procedia - Social and Behavioral Sciences, 58, $370-378$.

Myung H.Jin \& Mi Young Lee. (2012). The Effects Of Autonomy, Experience and Person-Organization Fit On Job Satisfaction: The Case Of Public Sector. The International Journal of Social Sciences, 6(1).

Naqvi S.M.M.Raza, Maria Ishtiaq, Nousheen Kanwal \& Mohsin Ali. (2013). Impact Of Job Autonomy On Organizational Commitment and Job Satisfaction: The Moderating Role Of Organizational Culture In Fast Food Sector Of Pakistan. International Journal Of Business and Management; 8(17).

Nicola S. Schutte (2014). The Broaden and Build Process: Positive Affect, Ratio Of Positive To Negative Affect and General Self-Efficacy. The Journal Of Positive Psychology, 9(1), 66-74.

Nikos Bozionelos. (2004). The Big Five Of Personality and Work Involvement. Journal Of Managerial Psychology, 19(1), 69-81.

Oladipo Kolapo Sakiru, Jamilah Othman, Abu Daud Silong, Salami Dada Kareem, Awotayo Olagoke, Oluwafemi \& Gafar OLanrewaju Yusuf. (2014). Relationship between Head of Department Leadership Styles and Lecturers Job Satisfactions in Nigerian Public Universities. Asian Social Science 10(6).

Oyewumi Adebomi, Ibitoye, Hannah. Olufunke, Sanni, Oleyemisi B. (2012). Job Satisfaction and Self-Efficacy As Correlates Of Job Commitment Of Special Education Teachers In Oyo State. Journal Of Education and Practice, 3(9).

Peter T. Van Den Berg \& Jan A. Feij. (2003). Complex Relationships Among Personality Traits, Job Characteristics and Work Behaviors. International Journal Of Selection and Assessment, 11(4), 326-339.

Peter Hosie, Payyazhi Jayashree, Abdellatif Tchantchane \& Ban Seng Lee (2013). The Effect Of Autonomy, Training Opportunities, Age And Salaries On Job Satisfaction In The South East Asian Retail Petroleum Industry. The International Journal of Human Resource Management, $24: 21,3980-4007$.

Pettijohn, C.E., Pettijohn, L.S. dan Taylor, A.J. (2002). The Influence Of Salesperson Skill, Motivation and Training On The Practice Of Customer-Oriented Selling. Psychology \& Marketing. 19(9). 743-757.

Ramendra, S. dan Gopal, D. (2013). The Impact Of Job Satisfaction, Adaptive Selling Behaviors and Customer Orientation On Salesperson's Performance: Exploring The Moderating Role Of Selling Experience. Journal of Business \& Industrial Marketing, 28(7), 554-564.

Rita E. McKenzie. (2000). Psychological Characteristics of Pre-service Elementary Teachers:Five Factor Model, Vocational Personality Characteristics, and Efficacy. Bell \& Howell Information dan Learning Company

Robert E. Wood \& Verena Marshall. (2008). Accuracy and Effectiveness In Appraisal Outcomes: The Influence Of Self-Efficacy, Personal Factors and Organizational Variables. Human Resource Management Journal, 18(3), 295-313.

Roger A. Federici. (2013). Principals' Self-Efficacy: Relations With Job Autonomy, Job Satisfaction, and Contextual Constraints. Eur J Psychol Educ, 73-86.

Saifuddin Khan Saif, Allah Nawaz, Farzdan Ali Jan, Muhammad Imran Khan. (2012). Synthesizing The Theories Of Job-Satisfaction Across The Cultural/Attitudinal Dementions. Interdisciplinary Journal Of Contemporary Research In Business, 3(9).

Sandra Gountas, John Gountas and Felix T Mavondo. (2014). Exploring The Associations Between Standards For Service Delivery (Organisational Culture), CoWorker Support, Self-Efficacy, Job Satisfaction And Customer Orientation In The Real Estate Industry. Australian Journal of Management, 39(1) 107126.

Scholz, U., Sniehotta, F. F., \& Schwarzer, R. (2005). Predicting Physical Exercise In Cardiac Rehabilitation: The Role Of Phase-Specific Self-Efficacy Beliefs. Journal Of Sport \& Exercise Psychology, 27, 135-151.

Seibert, S. E., \& Kraimer, M. L. (2001). The Five-Factor Model Of Personality and Career Success. Journal of Vocational Behavior, $58,1-21$.

Siti Fatimah Binti Mohd Ali \& Sarimah Bt. Ismail. (2008). Kepuasan Bekerja Di Kalangan Staf Sokongan Jabatan Pendidikan Teknikal Dan Kejuruteraan, Fakulti Pendidikan, Universiti Teknologi Malaysia. Theses.

Susanti Saragih. (2011). The Effects of Job Autonomy on Work Outcomes: Self Efficacy as an Intervening Variable. International Research Journal of Business Studies, $203-215$.

Sven Kepes. (2008). Sales Self-Efficacy: Scale Development and Nomological Validation. Proquest Llc

Ulfiani Rahman, Wan Shahrazad Wan Sulaiman, Rohany Nasir \& Fatimah Omar. (2014). The Role of Job Satisfaction as Mediator in the Relationship between SelfEfficacy and Organizational Citizenship Behavior among Indonesian Teachers. International Journal of Business and Social Science, 5, 9.

Vivian D. Cook. (2005). An Investigation of the Construct Validity of the Big Five Construct of Emotional Stability in Relation to Job Performance, Job Satisfaction and Career Satisfaction. ProQuest Information and Learning Company

Visser, C.F. (2010). Self-Determination Theory Meets Solution-Focused Change: Autonomy, Competence and Relatedness Support In Action, Interaction. The Journal Of Solution Focus In Organisations, 2(1), 7-26(20).

Yuhsuan Chang and Jodie K. Edwards. (2015). Examining the Relationships Among Self-Efficacy, Coping,and Job Satisfaction Using Social Career Cognitive Theory: An SEM Analysis. Journal of Career Assessment, 23(1) 35-47.

Zainal Ariffin, Lilis Surienty, Azura Abdullah Effendi, Jumaimah Jauhar, Siti Rohaida \& Tanjua Sharma (2009). Understanding organizational behavior. Kuala Lumpur: Oxford University Press.

Zainudin Awang, Junaidah Hanim Ahmad, Nazmi Mohamed Zin. (2010). Modelling Job Satisfaction and Work Commitment Among Lecturers: A Case Of UiTM Kelantan. Proceedings of the Regional Conference on Statistical Sciences 2010 (RCSS'10) June 2010, 241-25.

Zimmerman, R. D. (2008). Understanding The Impact Of Personality Traits On Individuals' Turnover Decisions: A Meta-Analytic Path Model. Personnel Psychology, 61(2), 309-348 